\title{
Ethnobotany of Pentadesma butyracea in Benin: A quantitative approach
}

\author{
C. Avocèvou-Ayisso, T.H. Avohou, M. \\ Oumorou, G. Dossou and B. Sinsin
}

\section{Research}

\begin{abstract}
Integrating ethnobotanical knowledge in the development of management and conservation strategies of indigenous plant resources is critical to their effectiveness. In this paper, we used four plant use indices to assess how the plant use knowledge of a multipurpose tree (Pentadesma butyracea Sabine) varies across different sociolinguistic groups from two geographical areas of Benin, and how these variations may influence the species' conservation and utilisation strategies. Seven sociolinguistic groups namely the Anii, Nagot, Kotocoli, and Fulani in the central part, and the Waama, Ditamari and Natimba in the northwestern part of the country were considered. We determined the reported use value of the plant parts, the plant part value, the specific use and the intraspecific use value for each sociolinguistic group. The various communities showed different interests in the plant organs they used. Nagot people showed the best plant use knowledge (highest use value) for $P$. butyracea bark and roots, two organs critical to the plant survival. Sociolinguistic groups living in the same geographical area shared similar plant part values, likely because of knowledge exchanges through social interactions. The observed intercultural convergences of uses may be a starting point of the selection of parts of the species for phytochemical, biological and pharmacological studies.
\end{abstract}

\section{Résumé}

L'intégration des connaissances ethnobotaniques dans le développement des stratégies de gestion et de conservation des ressources végétales endogènes est essentielle pour assurer leur efficacité. Nous avons utilisé quatre indices d'utilisation des plantes pour évaluer comment les connaissances d'utilisation de Pentadesma butyracea Sabine, une espèce à usages multiples, varient entre divers groupes sociolin- guistiques de deux zones géographiques distinctes du Bénin, et comment ces variations pourraient influencer les stratégies de conservation de l'espèce. Sept groupes sociolinguistiques à savoir les Anii, Nagot, Kotocoli, et Fulani au centre, et les Waama, Ditamari et Natimba au nord-ouest du pays, ont été considérés. Quatre valeurs d'usage à savoir le nombre d'usages rapportés par organe de la plante, la valeur de l'organe en question, des usages spécifiques et la valeur d'usage intraspécifique ont été calculées pour chaque groupe. Les diverses communautés ont montré des intérêts différents pour les divers organes de l'espèce utilisés. Les Nagot ont présenté le meilleur niveau de connaissances de $P$. butyracea et les valeurs d'usage les plus élevées pour l'écorce et les racines, deux des parties les plus essentielles pour la survie de l'espèce. Les groupes sociolinguistiques qui vivent dans la même aire géographique ont eu des valeurs d'usage proches, ce qui pourrait être le signe d'échanges de connaissances entre eux. Les convergences interculturelles d'usages observées peuvent

\section{Correspondence}

Carolle Avocèvou-Ayisso, G. Dossou \& B. Sinsin, Laboratory of Applied Ecology, Faculty of Agronomic Sciences, University of Abomey-Calavi, 03 BP 1974 Cotonou, BENIN.

c.avocevou@gmail.com

T.H. Avohou, Laboratory of Applied Ecology, Faculty of Agronomic Sciences, University of Abomey-Calavi, 03 BP 1974 Cotonou, BENIN and Bioversity International, West and Central Africa Office, 08 B.P. 0932, Cotonou, BENIN.

M. Oumorou, Polytechnic School of Abomey-Calavi, University of Abomey-Calavi, Cotonou, BENIN.

Ethnobotany Research \& Applications 10:151-166 (2012)

Published: April 16, 2012 
être un point de départ de sélection d'organes de l'espèce pour des études ultérieures de phytochimie, de biologie et de pharmacologie.

\section{Introduction}

Focusing on the knowledge, use, and management of plants by people may improve our understanding of the nature of management problems and options for conservation at local and regional levels (Dalle \& Potvin 2004). Local knowledge of the use and conservation of plant resources may vary with environmental factors such as species richness, abundance of useful plants or common diseases, and cultural heritages of the people exploiting these resources (Ali-Shtayeh et al. 2008, Arias Toledo et al. 2007, Hadjichambis et al. 2007, Hilgert \& Gil 2006). The importance of studying variations in knowledge across cultural groups lies in the fact that relationships between people and nature may differ from a cultural group to another. Therefore, within a same geographical or ecological area, people's perceptions and practices of natural resources management and use at the local level may vary with their background and ancestral inheritance. For example, comparisons can be made among cultural groups because of their long-time cultural interactions, the lack of kinship and the contact with a same outsider group or ecosystem (Coe 2008).

Previous ethnobotanical studies suggest that many individual attributes such as age, gender, ethnicity, roles and responsibilities at household and community levels, profession, aptitude and intellectual abilities, and control over natural resources may influence indigenous knowledge of natural resources within the same community (Ayantunde et al. 2008). For instance, studies revealed that older people generally know more useful plants than younger people do (Gemedo-Dalle et al. 2005) and we can expect that education and labor responsibilities influence the knowledge of women and men in a given cultural group (Ayantunde et al. 2008, Kristensen \& Lykke 2003).

These patterns in traditional knowledge among and within cultural groups can be better-deciphered using quantitative ethnobotany approaches. Contrary to earlier ethnobotanical studies which simply documented traditional botanical knowledge (Fernandez et al. 2003, Frei et al. 1998, Giday et al. 2003, Lykke 2000), quantitative ethnobotany allows explicit, repeatable and systematic data collection, and a broader scope of potential variables that can allow statistical analyses and hypotheses testing. One of the applications of quantitative techniques in ethnobotany is the comparison of the uses and the cultural importance of various plant taxa among different cultural groups (Gomez-Beloz 2002, Phillips \& Gentry 1993a, 1993b).
Phillips (1996) suggested three quantitative methods to measure plant importance based on local uses: (1) the informant consensus or informant-indexing method, (2) the subjective allocation method, and (3) the uses totalled method. In the informant consensus method, the relative importance of each resource is calculated directly from the degree of agreement among the different people interviewed on the uses of the resource (Phillips 1996). In the subjective allocation method, the researcher subjectively assigns a relative importance to each use based on the cultural significance of each plant or use (Phillips 1996). In the uses totalled approach, no attempt is made to quantify the relative importance of each use; numbers of uses are simply totalled by category of plant use, plant taxon, or vegetation type.

In this study, we used the informant consensus method to analyze the intercultural variations of Pentadesma butyracea Sabine uses among seven different sociolinguistic groups from two distinct geographical areas of Benin. This method has been widely used by several authors to investigate the impact of exploitation on locally important resources, based on the assumption that the more important a resource is, the greater the exploitation pressure will be (e.g. Albuquerque et al. 2006, Phillips \& Gentry 1993a, Heinrich et al. 1998, Gomez-Beloz 2002, Collins et al. 2006).

P. butyracea is an evergreen tree which occurs in areas scattered from Guinea, Sierra-Leone, Côte d'Ivoire, Togo, and Benin to the Democratic Republic of Congo, extending eastwards into Tanzania and Uganda where it is being domesticated (Sama \& Sacandé 2007). In Benin, its natural stands occur mostly in endangered ecosystems of riparian forests that stretch along rivers into areas with a diversity of people and cultures (Natta et al. 2002, 2003). We conducted the study in Benin because the species is more and more threatened by the exploitation of its organs in this country (Sinsin \& Sinadouwirou 2003). P. butyracea is a multi-purpose tree, which supplies many indigenous people with a diversity of valuable non-timber forest products (NTFPs) in Benin. The kernel is its main harvested product and is processed into butter and marketed (Avocèvou-Ayisso et al. 2009, Houngbédji 1997, Sinsin \& Sinadouwirou 2003). Its leaves, bark and roots are used to treat various diseases (Houngbédji 1997, Sinsin \& Sinadouwirou 2003), and its wood is carved and used for construction.

The objective of the study is twofold: (1) to assess similarities in the use knowledge of $P$. butyracea among the main sociolinguistic groups of the areas where the species most abounds, (2) to identify intercultural convergences of specific uses of $P$. butyracea parts. 


\section{Avocèvou-Ayisso et al. - Ethnobotany of Pentadesma butyracea in Benin: A quantitative approach}

\section{Material and Methods}

\section{Study species}

The species description was extracted from Hutchinson and Dalziel (1954), Aubreville (1959), Vivien (1988), and Sama \& Sacandé (2007). Pentadesma butyracea (Clusiaceae) is a large tree with up to $15-30 \mathrm{~m}$ of height and 100$150 \mathrm{~cm}$ of diameter at breast height. Its bark is brownish with small rectangle-shaped fissures. Its leaves are simple, entire and 10 to $22 \mathrm{~cm}$-long and 3.5 to $7 \mathrm{~cm}$-broad. Its flowers are large, yellowish white or whitish red, solitary or in cluster (2 to 6). In Benin, flowering starts in September and reaches its maximum in November. The fruits are reddish-green and ellipsoid berries measuring approximately $11 \mathrm{~cm}$-broad and $15 \mathrm{~cm}$-long. They contain several (1-15) embedded seeds. The seeds are large and contain dark red embryos. Oil is extracted from the seeds.

\section{Study area}

The study was carried out in the communes of Bassila and Toucountouna (Figure 1), the two most important areas in terms of abundance of the species in Benin. Bassila is located in the central part of Benin $\left(8^{\circ} 30^{\prime}-9^{\circ} 30^{\prime} \mathrm{N}\right.$ and $1^{\circ} 00^{\prime}-2^{\circ} 30^{\prime} \mathrm{E}$ ), in the Sudano-Guinean transitional climatic zone with one rainy season (May to October) and one dry season (November to April). Annual rainfall averages 850 - $1870 \mathrm{~mm}$. The major soil types include sandy to silt-sandy ferruginous, ferrallitic and hydromorphic soils. The vegetation consists of riparian and dry dense forests, woodlands, tree and shrub savannas, and plantations of Tectona grandis L.f., Anacardium occidentale L. and Gmelina arborea Roxb. ex Sm. (PRRF 1998). The population of this area is approximately 74,664 inhabitants and consists of four main sociolinguistic groups namely the Anii, Nagot, Kotocoli and Fulani people, each group representing respectively about $38,27,15$ and 10 percent of the population (INSAE 2006).

Toucountouna is located in the northwestern part of $\mathrm{Be}$ $\operatorname{nin}\left(10^{\circ} 20^{\prime}-10^{\circ} 45^{\prime} \mathrm{N}\right.$ and $\left.1^{\circ} 10^{\prime}-1^{\circ} 40^{\prime} \mathrm{E}\right)$ in the Sudanian climatic zone (Figure 1 ) with one rainy season (April to October) and an average annual rainfall of $1200 \mathrm{~mm}$. Two types of soils are prominent: the ferruginous silt-sandy soils and the silt-clayey soils. The vegetation consists mostly of savannas dominated by species such as Isoberlinia doka Craib \& Stapf, Isoberlina tomentosa (Harms) Craib \& Stapf, Adansonia digitata L., Borassus aethiopum Mart., Burkea africana Hook. and Daniellia oliveri (Rolfe) Hutch. \& Dalziel. Riparian forests with abundant $P$. butyracea are also common along rivers. The population is approximately 35,315 inhabitants and consists of three major sociolinguistic groups namely the Waama, the Ditamari and the Natimba people, representing respectively about 52, 23 and 18 percent of the population (INSAE 2006).
In both regions, the local economy relies on subsistence agriculture, livestock farming, and the processing and commercialization of non-timber forest products (e.g., nuts of Vitellaria paradoxa C.F. Gaertn., P. butyracea, Parkia biglobosa (Jacq.) R. Br. ex G. Don, and Saba comorensis (Bojer ex A. DC.) Pichon).

Except for the Fulani people who live as herder communities often in the bush or in camps around villages, the other communities are mainly farmers. Though one community may dominate in a village, many communities usually live together in the same village, and no group lives in isolation

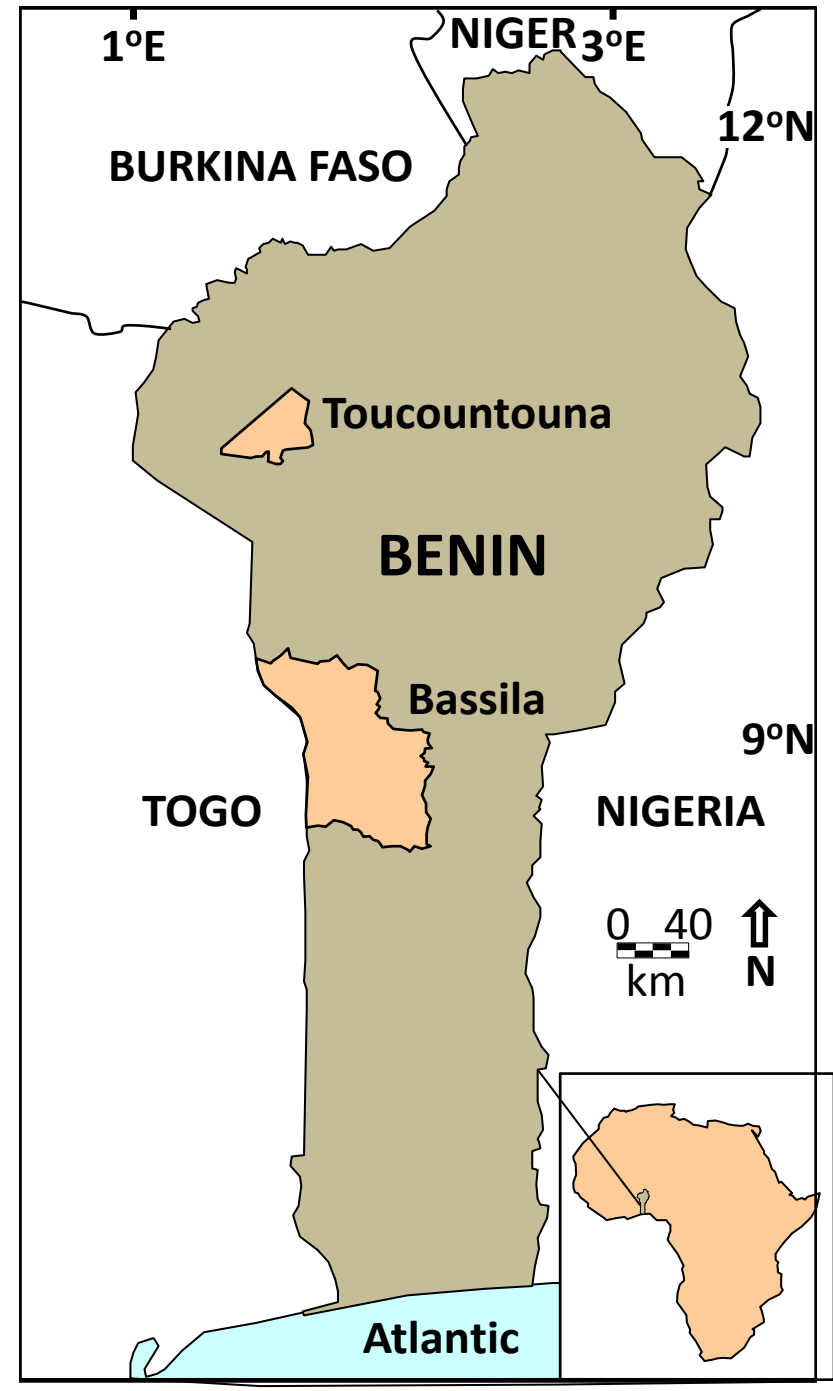

Figure 1. Location of the study areas in Bassila and Toucountouna, Benin. 


\section{Data collection and analysis}

We collected data through individual interviews of informants based on a questionnaire. Interviews covered the periods from October 2006 to January 2007 and from February to March 2008. Prior to the interviews, we organized community meetings at village levels in each of the two areas to discuss our research plans with locals and seek their agreement to undertake the work. In each of the two areas, we held four community meetings in four villages with groups of 50 to 60 persons including village heads, members of peasant associations, traditional healers and women. After the community meetings, we sampled 200 informants among volunteers in the two areas (Table 1). During the exploratory stages, we learned that people younger than 22 years had limited use knowledge of the parts of $P$. butyracea except the processing of kernels into butter. Older people of the communities held the core ethnobotanical information on the species. Therefore, the sampling consisted in selecting randomly selected volunteers among middle-aged and elderly people, including traditional healers, herbalists and women who were involved in fruit harvesting and kernel processing. Each respondent provided a verbal consent. This sampling method shows the advantage of eliminating possible bias related to the reluctance of some respondents to share their knowledge. However, if people unwilling to participate in the study were those holding more knowledge on the species, this approach might have underestimated the use values we estimated.

Interviews were conducted individually to prevent informants from being influenced by each other. We ensured respondents of the anonymity of the information provided to increase the chances that they would provide genuine answers (Henerson et al. 1987). The questionnaire included two sections. The first section dealt with basic demographics (e.g., sociolinguistic group, age, gender,

Table 1. Distribution of the respondents to a questionnaire about ethnobotany of Pentadesma butyracea Sabine across the main sociolinguistic groups in Bassila and Toucountuna communes, Benin.

\begin{tabular}{|l|l|l|l|}
\hline Area & $\begin{array}{l}\text { Sociolinguistic } \\
\text { groups }\end{array}$ & $\begin{array}{l}\text { Number of } \\
\text { respondents }\end{array}$ & $\begin{array}{l}\text { Proportion of the } \\
\text { sample size (\%) }\end{array}$ \\
\hline \multirow{3}{*}{ Bassila } & Anii & 55 & 43.7 \\
\cline { 2 - 4 } & Nagot & 35 & 27.8 \\
\cline { 2 - 4 } & Kotocoli & 22 & 17.5 \\
\cline { 2 - 4 } & Fulani & 13 & 10.4 \\
\cline { 2 - 4 } & Sub-total 1 & 125 & 100 \\
\hline \multirow{3}{*}{ Toukountuna } & Waama & 40 & 53.3 \\
\cline { 2 - 4 } & Ditamari & 23 & 30.7 \\
\cline { 2 - 4 } & Natimba & 12 & 16.0 \\
\cline { 2 - 4 } & Sub-total 2 & 75 & 100 \\
\hline Total & & 200 & \\
\hline
\end{tabular}

education level, etc.) and the other dealt with plant-use knowledge. Questions were translated into the language of each sociolinguistic group with the assistance of native interpreters. We formulated them in culturally appropriated and meaningful ways, using concepts that were not foreign to the cultural system of meaning. We also tested the questionnaire in each area during a pilot survey (Luoga et al. 2000) to ensure that interpreters, respondents and we correctly understood the questions. This process allowed us to limit information distortion through translation. Interviews lasted 40-60 minutes per respondent.

During the administering of the plant-use knowledge section, we investigated people's knowledge in terms of their ability to identify the species and describe the uses of its organs. We showed informants fresh leaves, fruits and kernels of the species and asked them to identify, name and describe them in their mother language. We then asked them to list and describe the uses of the species they knew including medicinal, cosmetic, timber, food, magico-mystic, lactogenic uses, and if they personally used it. In addition to plant parts traditionally considered such as leaves, fruits, flowers, bark and roots, we added young leaves, suckers, kernels and butter, which have specific uses in the area. To record medicinal uses, we used a classification developed by Cook (1995) and used by Collins et al. (2006). This classification was based on medical conditions that affect a system of the human body. Thus, diseases were categorized into circulatory system disorders, digestive system disorders, genitourinary system disorders, etc. To reflect the entire local context, we added other functional categories to the former defined by Cook (1995). These included magico-mystic, cosmetic, timber, and lactogenic, immune system and baby's dentition reinforcement uses.

We determined various plant use indices as defined by Gomez-Beloz (2002). However, we focused our study on the estimation of use values since we worked on one species while Gomez-Beloz (2002) worked on several species. We computed the following indices:

1. The reported use value $(R U)$ : It is the total number of uses reported for the plant. The reported use value of the species was broken down by the number of uses reported for each plant part $\left(\Sigma R U_{\text {[plant part] }}\right)$.

2. The plant part value (PPV): It is a value given for a specific plant part. It is equal to the ratio between the number of total uses reported for each plant part and the total number of re- 


\section{Avocèvou-Ayisso et al. - Ethnobotany of Pentadesma butyracea in Benin: A quantitative approach}

ported uses for the plant: PPV $=\left(\Sigma R U_{\text {[plant part] }} / R U\right)$. Organs showing high values of PPV are the most often used parts of the species by respondents from a sociolinguistic group.

3. The specific reported use (SU): It is the use as described by the respondents. The use descriptions have been simplified to facilitate analyses. The SU value refers to the number of times a specific reported use is mentioned by the respondents from a sociolinguistic group.

4. The intraspecific use value (IUV): It is the ratio of the specific reported use and the reported use for the plant part: IUV $=S U_{\text {[plant part] }} / R U_{\text {[plant part] }}$ The intraspecific use value allows the ordering of use importance within a specific plant part. It helps to identify for a specific plant part, the most frequently reported specific uses by the respondents from a sociolinguistic group. High values of IUV for a specific use generally indicate a consensus in this use of the concerned part within a sociolinguistic group.

We used a generalized linear model with Poisson error distribution and log-link function to assess the variations of the individual RU (that is the number of uses reported per informant), according to sociolinguistic group, gender and age. We used principal components analysis (PCA) to assess similarities (correlations) among the sociolinguistic groups based on the importance of plant organs used (represented by the calculated plant part values).

\section{Results}

\section{Reported Use Values of $P$. butyracea}

$\mathrm{RU}$ varied significantly among sociolinguistic groups $(p=0.0194)$ and between gender within each group ( $p=0.0003$ ). Nagot (1.5 \pm 1 uses/informant) and Waama (1.8 \pm 1 uses/informant) people reported less uses than Anii (2.3 \pm 1.3 uses/informant), Ditama-

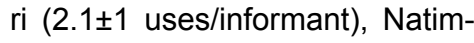
ba (2.4 \pm 1.6 uses/informant), Fulani (2.5 \pm 1.4 uses/informant) and Kotocoli people (2.0 $\pm 1.0 /$ infor- mant) did. Women (1.7 \pm 1.1 uses/informant) reported less uses than men did (2.3 \pm 1.2 uses/informant). In contrast, age did not influence the number of uses reported per informant. Even if older people seemed to report more uses of the species than younger people did, the differences were not significant $(p=0.7216)$. Moreover, there was no interaction among the three factors namely sociolinguistic group, gender and age.

The result of the principal component analysis (PCA) performed on plant part values showed that the first two dimensions explained more than $75 \%$ of the observed variation (Table 2a). Therefore, these two dimensions were used to describe the relationships between the use of the plant organs and sociolinguistic groups. To describe the PCA dimensions, only variables which were significantly correlated with them at a probability level of 0.15 were kept (Table 2a). The first dimension was positively correlated with the values of flowers, bark, pulp, young

Table 2a. Description of the PCA dimensions by their correlation coefficients with the initial plant part values from a questionnaire about ethnobotany of Pentadesma butyracea Sabine. Figures in red indicate variables which described the best each dimension (correlation coefficient significant at 0.15).

\begin{tabular}{|l|r|r|r|r|}
\hline \multirow{2}{*}{ Variables (Plant } & \multicolumn{2}{l|}{ Dimension 1 (45.63\%) } & \multicolumn{2}{l|}{ Dimension 2 (30.51\%) } \\
\cline { 2 - 5 } & Correlation & \multicolumn{1}{l|}{ p-value } & \multicolumn{1}{l|}{ Correlation } & p-value \\
\hline Leaves & -0.879 & 0.009 & 0.199 & 0.668 \\
\hline Flowers & 0.924 & 0.003 & 0.238 & 0.608 \\
\hline Pulp & 0.654 & 0.111 & -0.442 & 0.321 \\
\hline Kernels & -0.003 & 0.995 & 0.867 & 0.011 \\
\hline Bark & 0.628 & 0.131 & 0.759 & 0.048 \\
\hline Roots & 0.488 & 0.266 & 0.615 & 0.142 \\
\hline Timber & -0.828 & 0.022 & 0.501 & 0.252 \\
\hline Butter & -0.512 & 0.240 & -0.500 & 0.274 \\
\hline Young leaves & 0.630 & 0.130 & -0.387 & 0.391 \\
\hline Fruit & 0.659 & 0.107 & 0.553 & 0.198 \\
\hline Suckers & -0.744 & 0.055 & 0.648 & 0.115 \\
\hline
\end{tabular}

Table 2b. Quality of the representation (squared cosine) of sociolinguistic groups and their coordinates in the first three dimensions of the PCA. Figures in red indicate sociolinguistic groups which were best represented $\left(\cos ^{2}\right.$ close to or greater than 0.5) and their coordinates on each dimension.

\begin{tabular}{|l|r|r|r|r|}
\hline \multirow{2}{*}{$\begin{array}{l}\text { Sociolinguistic } \\
\text { groups }\end{array}$} & \multicolumn{2}{|l|}{ Dimension 1 (45.63\%) } & \multicolumn{2}{l|}{ Dimension 2 (30.51\%) } \\
\cline { 2 - 5 } & Coordinates & Cos $^{2}$ & Coordinates & Cos $^{2}$ \\
\hline Anii & 1.685 & 0.399 & -0.498 & 0.035 \\
\hline Kotocoli & 1.832 & 0.471 & -1.425 & 0.285 \\
\hline Peulh & 1.398 & 0.481 & -0.379 & 0.035 \\
\hline Nagot & 2.435 & 0.331 & 3.062 & 0.523 \\
\hline Waama & -2.585 & 0.689 & 1.167 & 0.140 \\
\hline Ditamari & -3.611 & 0.799 & 1.095 & 0.073 \\
\hline Natimba & -1.155 & 0.091 & -3.022 & 0.620 \\
\hline
\end{tabular}


leaves and fruit, and negatively correlated with the values of leaves, timber, suckers, and to a lesser extent butter (Table 2a). The second dimension was positively correlated with the values of kernels, bark, suckers and roots, and negatively correlated to a lesser extent with the value of butter.

Based on the quality of the representation and the position of the seven sociolinguistic groups on the two PCA dimensions (Table $2 \mathrm{~b}$ ), four categories of sociolinguistic groups showing similarities in the organs they used may be distinguished (Figure 2):

-Group $G_{1}$ was characterized by high values for leaves, suckers and timber, and included Ditamari and Waama people. This group was also associated with high values for butter;

-Group $G_{2}$ was characterized by low values for kernels, bark, suckers, and roots, and high values for butter and included Natimba people only;

-Group $\mathrm{G}_{3}$ included Anii, Kotocoli and Fulani people and was characterized by high values for flowers, fruit, pulp, bark and young leaves;
-Group $\mathrm{G}_{4}$ included Nagot people and was characterized by high values for kernels, bark, roots and suckers.

Moreover, sociolinguistic groups that were living in the same geographical area shared similar part values. The first two groups $\left(G_{1}\right.$ and $\left.G_{2}\right)$ lived in Toucountouna area and were more interested in the marketable products especially the butter and timber whereas the last two groups $\left(G_{3}\right.$ and $\left.G_{4}\right)$ lived in Bassila area and were more interested in the food and medicinal products of the species especially the fruit, pulp, bark, flowers and roots (Figure 2).

\section{Intercultural Convergence of Specific uses of $P$. butyracea parts}

Examples of IUV calculation are presented in Table 3a for the Ditamari group and Tables $3 b$ to $3 g$ for the other groups. Bark was reported to treat digestive system disorders by the Anii, Nagot, Waama and Ditamari respondents (IUV $=0.303,0.316,0.267$ and 0.300 respectively). In contrast, in the Kotocoli, Fulani and Natimba sociolinguistic groups, bark was used mostly to treat infections, genitourinary system disorders and circulatory system disorders (IUV $=0.400,0.250$ and 0.500 respectively).

Roots were reported to treat digestive system disorders by the Anii, Waama and Ditamari respondents (IUV

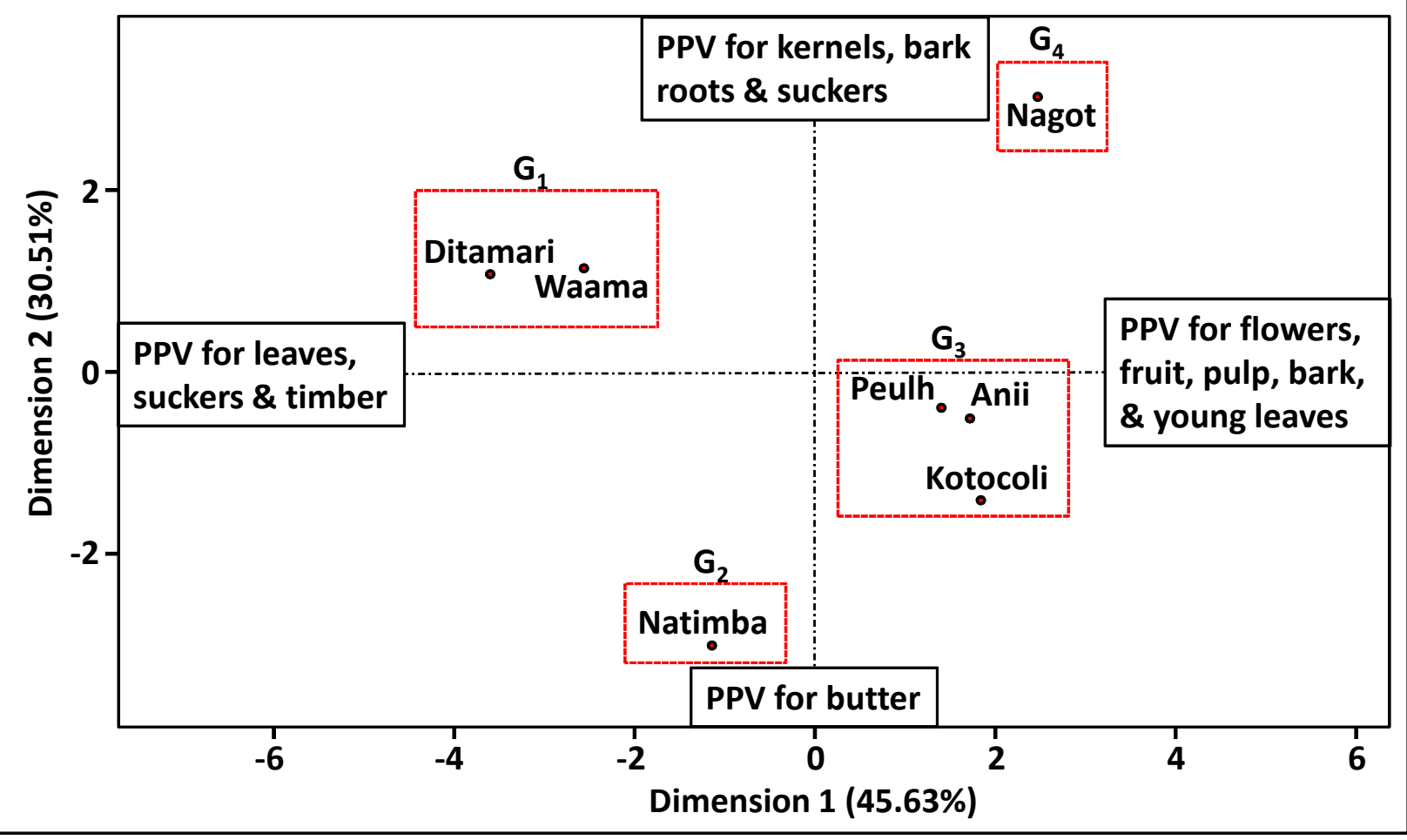

Figure 2. Specialization of sociolinguistic groups in the use of Pentadesma butyracea Sabine parts (the two axes represent the first two dimensions of the PCA with more than $75 \%$ of the total variance) in Bassila and Toucountuna communes, Benin. 


\section{Avocèvou-Ayisso et al. - Ethnobotany of Pentadesma butyracea in Benin: A 157 quantitative approach}

Table 3a. Importance indices for uses of Pentadesma butyracea Sabine organs by Ditamari people of Toucountouna commune, Benin. $\mathrm{RU}_{\text {plant part }}$ plant part reported use; $\mathrm{RU}=$ reported use ; PPV = plant part value ; SU = specific use; IUV $=$ Intraspecific use-value.

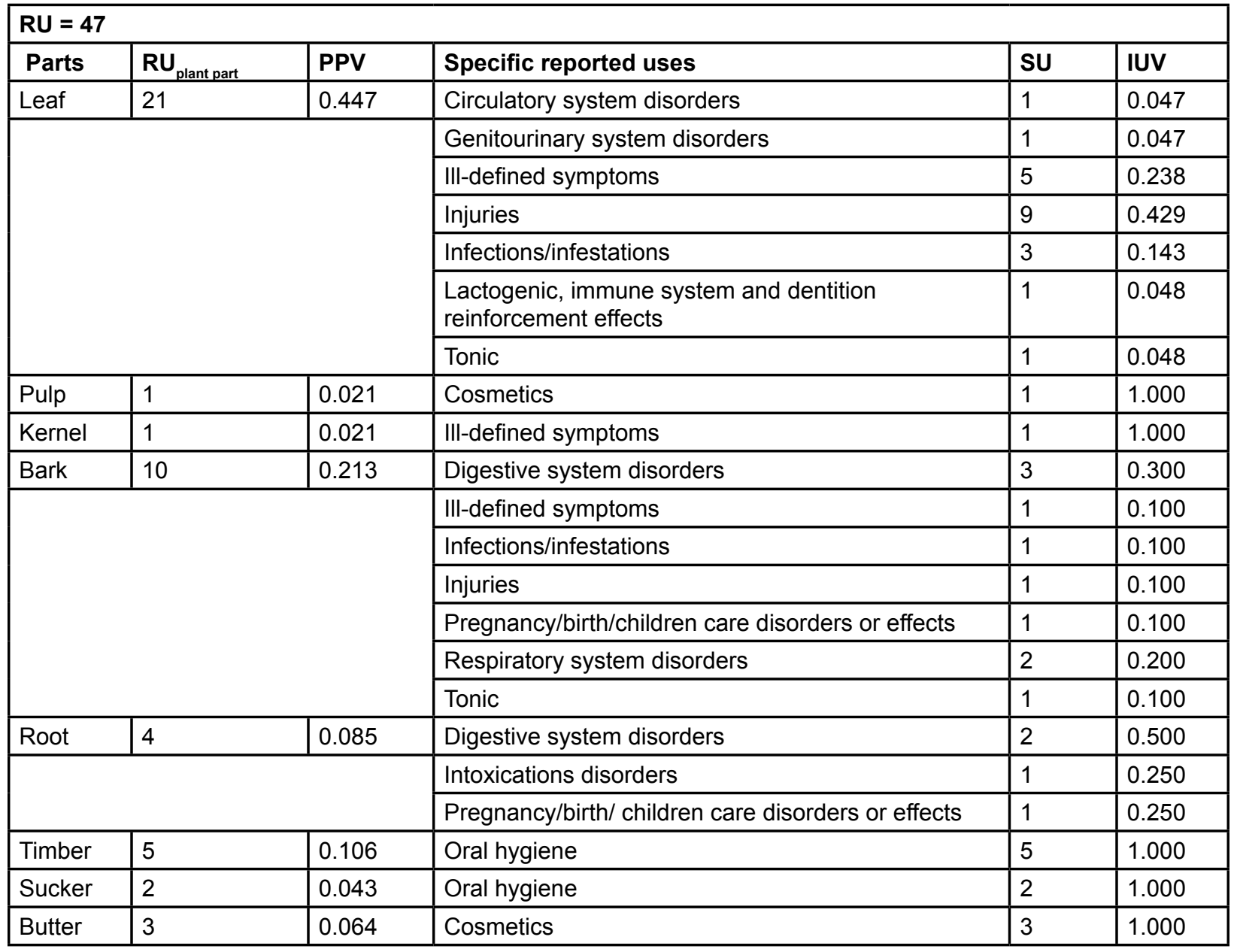

Table 3b. Importance indices for the uses of Pentadesma butyracea Sabine organs by Anii people of Bassila commune, Benin. $\mathrm{RU}_{\text {plant part }}$ plant part reported use; $\mathrm{RU}=$ reported use ; PPV = plant part value ; SU = specific use; IUV = Intraspecific use-value.

\begin{tabular}{|c|c|c|c|c|c|}
\hline \multicolumn{6}{|c|}{ RU = 129} \\
\hline Parts & $R \mathbf{U}_{\text {plant part }}$ & PPV & Specific reported uses & SU & IUV \\
\hline \multirow[t]{7}{*}{ Leaf } & 20 & 0.155 & Digestive System Disorders & 1 & 0.050 \\
\hline & & & Genitourinary System Disorders & 1 & 0.050 \\
\hline & & & III-Defined Symptoms & 4 & 0.200 \\
\hline & & & Metabolism Disorders & 1 & 0.050 \\
\hline & & & Pregnancy/Birth/Puerperium Disorders/Effects & 8 & 0.400 \\
\hline & & & Infections/Infestations & 2 & 0.100 \\
\hline & & & Tonic & 3 & 0.150 \\
\hline \multirow[t]{4}{*}{ Flower } & 5 & 0.039 & Digestive System Disorders & 2 & 0.400 \\
\hline & & & III-Defined Symptoms & 1 & 0.200 \\
\hline & & & Infections/Infestations & 1 & 0.200 \\
\hline & & & $\begin{array}{l}\text { Lactogenic effects/immune reinforcement and } \\
\text { dentition }\end{array}$ & 1 & 0.200 \\
\hline
\end{tabular}




\begin{tabular}{|c|c|c|c|c|c|}
\hline \multicolumn{6}{|c|}{ RU $=129$} \\
\hline Parts & $\mathbf{R U}_{\text {plant part }}$ & PPV & Specific reported uses & su & IUV \\
\hline \multirow[t]{6}{*}{ Pulp } & 6 & 0.047 & Circulatory System Disorders & 1 & 0.167 \\
\hline & & & Digestive System Disorders & 1 & 0.167 \\
\hline & & & Muscular-Skeletal System Disorders & 1 & 0.167 \\
\hline & & & Infections/Infestations & 1 & 0.167 \\
\hline & & & Tonic & 1 & 0.167 \\
\hline & & & Kitchen utensils' cleaning & 1 & 0.167 \\
\hline \multirow[t]{14}{*}{ Bark } & 33 & 0.256 & Circulatory System Disorders & 1 & 0.030 \\
\hline & & & Digestive System Disorders & 10 & 0.303 \\
\hline & & & Genitourinary System Disorders & 4 & 0.121 \\
\hline & & & III-Defined Symptoms & 1 & 0.030 \\
\hline & & & Injuries & 1 & 0.030 \\
\hline & & & Inflammation & 1 & 0.030 \\
\hline & & & Metabolic System Disorders & 1 & 0.030 \\
\hline & & & Muscular-Skeletal System Disorders & 3 & 0.091 \\
\hline & & & Pregnancy/Birth/Puerperium Disorders/Effects & 1 & 0.030 \\
\hline & & & Respiratory System Disorders & 1 & 0.030 \\
\hline & & & Infections/Infestations & 3 & 0.091 \\
\hline & & & Tonic & 2 & 0.061 \\
\hline & & & Magico-mystics & 4 & 0.121 \\
\hline & & & Nervous System Disorders & 1 & 0.030 \\
\hline \multirow[t]{10}{*}{ Root } & 23 & 0.178 & Circulatory System Disorders & 2 & 0.087 \\
\hline & & & Digestive System Disorders & 10 & 0.435 \\
\hline & & & Genitourinary System Disorders & 1 & 0.043 \\
\hline & & & III-Defined Symptoms & 3 & 0.130 \\
\hline & & & Inflammation & 1 & 0.043 \\
\hline & & & Skin Disorders & 1 & 0.043 \\
\hline & & & Infections/Infestations & 1 & 0.043 \\
\hline & & & $\begin{array}{l}\text { Lactogenic effects/ immune reinforcement and } \\
\text { dentition }\end{array}$ & 1 & 0.043 \\
\hline & & & Tonic & 2 & 0.087 \\
\hline & & & Magico-mystics & 1 & 0.043 \\
\hline \multirow[t]{6}{*}{$\begin{array}{l}\text { Young } \\
\text { leaf }\end{array}$} & 42 & 0.326 & Circulatory System Disorders & 3 & 0.071 \\
\hline & & & Genitourinary System Disorders & 1 & 0.024 \\
\hline & & & Respiratory System Disorders & 1 & 0.024 \\
\hline & & & Infections/Infestations & 1 & 0.024 \\
\hline & & & $\begin{array}{l}\text { Lactogenic effects/ immune reinforcement and } \\
\text { dentition }\end{array}$ & 35 & 0.833 \\
\hline & & & Magico-mystics & 1 & 0.024 \\
\hline
\end{tabular}




\section{Avocèvou-Ayisso et al. - Ethnobotany of Pentadesma butyracea in Benin: A quantitative approach}

Table 3c. Importance indices for the uses of Pentadesma butyracea Sabine organs by Kotocoli people of Bassila commune, Benin. $\mathrm{RU}_{\text {plant part }}$ plant part reported use; $\mathrm{RU}=$ reported use $; \mathrm{PPV}=$ plant part value ; $\mathrm{SU}$ = specific use; IUV $=$ Intraspecific use-value.

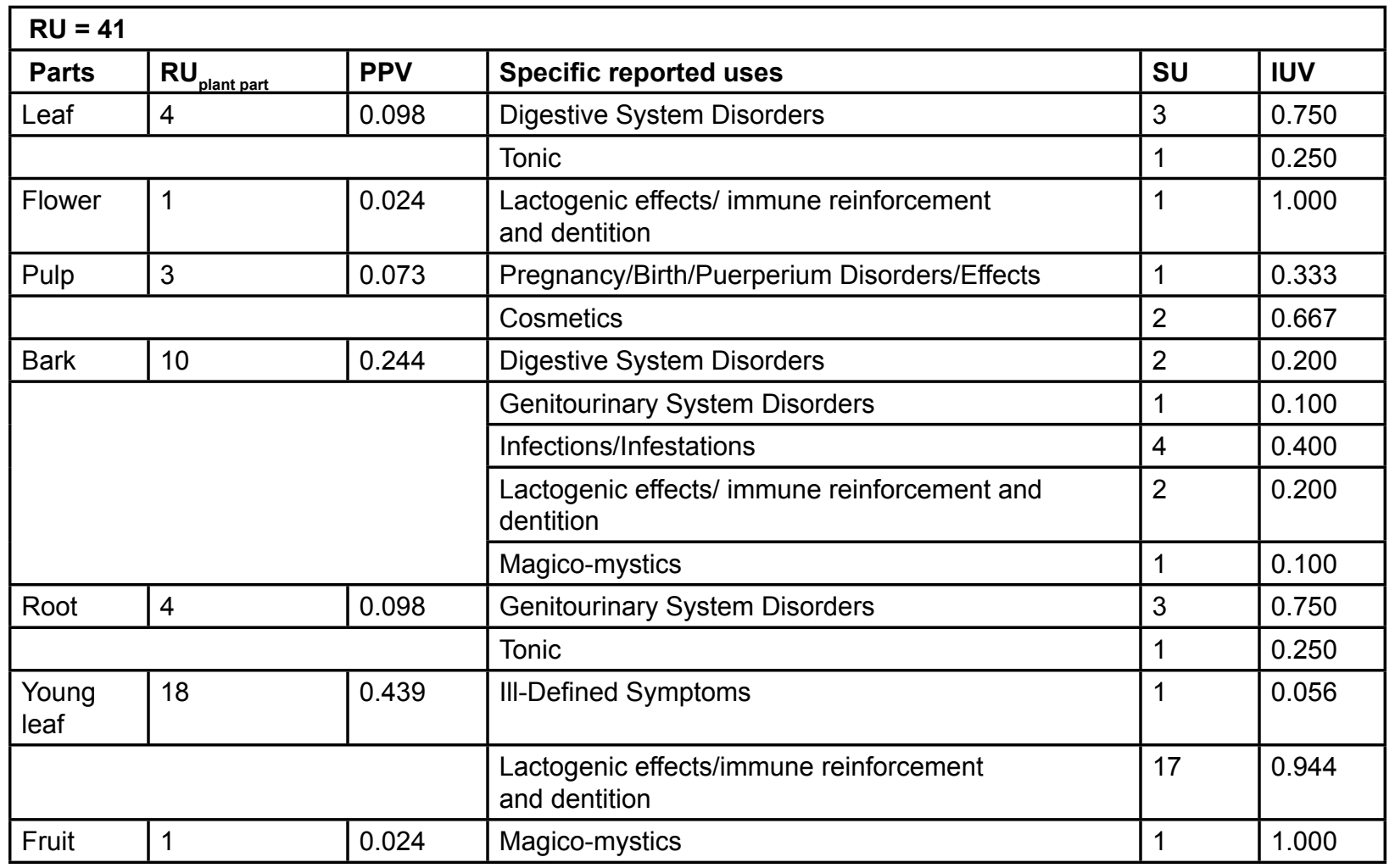

Table 3d. Importance indices for the uses of Pentadesma butyracea Sabine organs by Nagot people of Bassila commune, Benin. $\mathrm{RU}_{\text {plant part }}$ plant part reported use; $\mathrm{RU}$ = reported use ; PPV = plant part value ; $\mathrm{SU}$ = specific use; IUV $=$ Intraspecific use-value.

\begin{tabular}{|c|c|c|c|c|c|}
\hline \multicolumn{6}{|c|}{$R U=53$} \\
\hline Parts & $\mathbf{R U}_{\text {plant part }}$ & PPV & Specific reported uses & SU & IUV \\
\hline \multirow[t]{3}{*}{ Leaf } & 7 & 0.132 & Circulatory System Disorders & 2 & 0.286 \\
\hline & & & Genitourinary System Disorders & 1 & 0.143 \\
\hline & & & Infections/Infestations & 4 & 0.571 \\
\hline \multirow[t]{2}{*}{ Flower } & 2 & 0.038 & Digestive System Disorders & 1 & 0.500 \\
\hline & & & III-Defined Symptoms & 1 & 0.500 \\
\hline \multirow[t]{2}{*}{ Pulp } & 4 & 0.075 & Digestive System Disorders & 3 & 0.750 \\
\hline & & & Injuries & 1 & 0.250 \\
\hline \multirow[t]{3}{*}{ Kernel } & 3 & 0.057 & Inflammation & 1 & 0.333 \\
\hline & & & Muscular-Skeletal System Disorders & 1 & 0.333 \\
\hline & & & Respiratory System Disorders & 1 & 0.333 \\
\hline \multirow[t]{3}{*}{ Bark } & 19 & 0.358 & Circulatory System Disorders & 1 & 0.053 \\
\hline & & & Digestive System Disorders & 6 & 0.316 \\
\hline & & & Genitourinary System Disorders & 1 & 0.053 \\
\hline
\end{tabular}




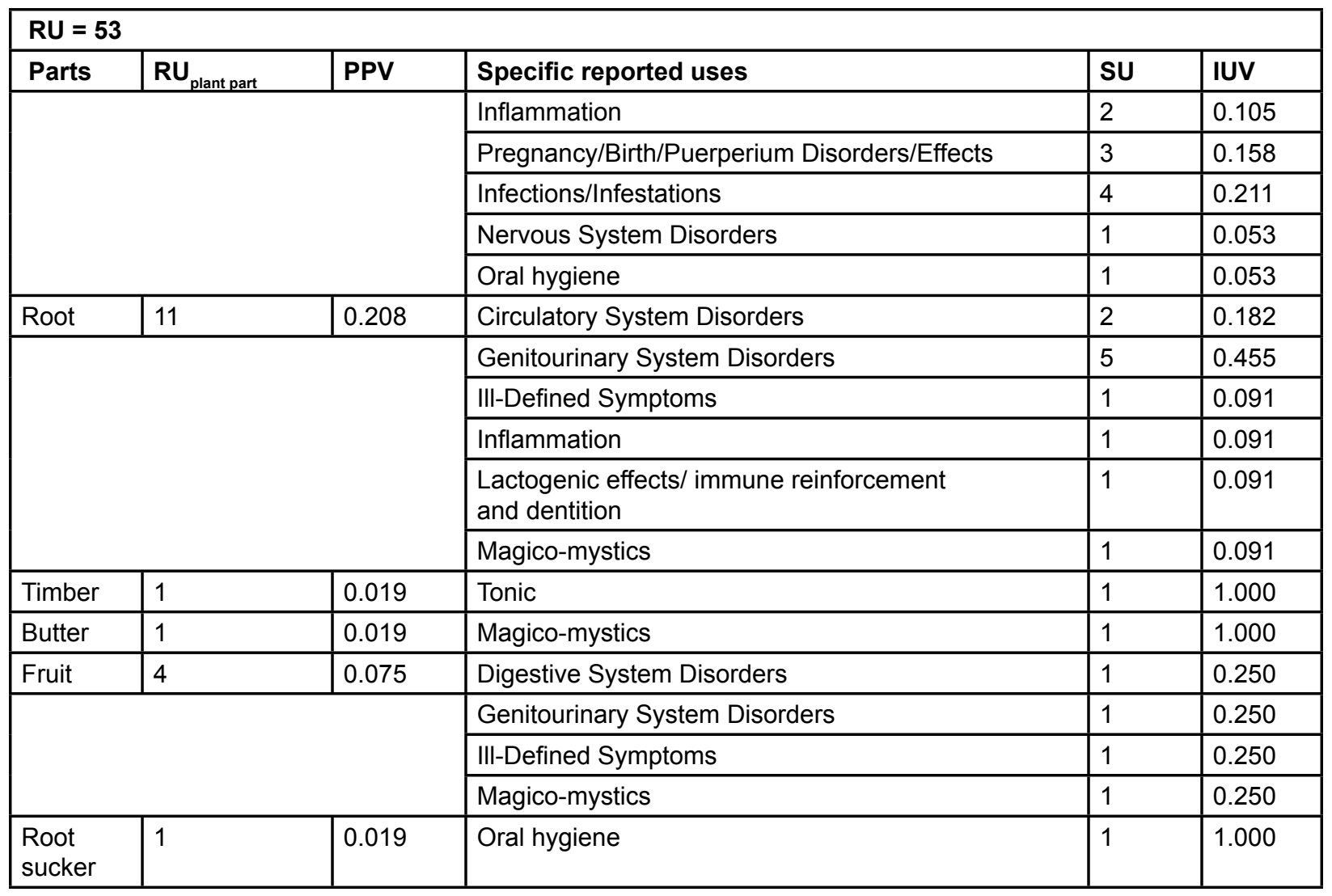

Table 3e. Importance indices for the uses of Pentadesma butyracea Sabine organs by Waama people of Toucountouna commune, Benin. $\mathrm{RU}_{\text {plant part }}$ plant part reported use; $\mathrm{RU}=$ reported use ; PPV = plant part value ; $\mathrm{SU}$ = specific use; IUV $=$ Intraspecific use-value.

\begin{tabular}{|c|c|c|c|c|c|}
\hline \multicolumn{6}{|c|}{$R U=73$} \\
\hline Parts & $\mathbf{R U _ { \text { plant part } }}$ & PPV & Specific reported uses & SU & IUV \\
\hline Leaf & 18 & 0.247 & Digestive System Disorders & 1 & 0.056 \\
\hline & & & Genitourinary System Disorders & 2 & 0.111 \\
\hline & & & III-Defined Symptoms & 4 & 0.222 \\
\hline & & & Injuries & 8 & 0.444 \\
\hline & & & Metabolic System Disorders & 2 & 0.111 \\
\hline & & & Infections/Infestations & 1 & 0.056 \\
\hline Pulp & 1 & 0.014 & Cosmetics & 1 & 1.000 \\
\hline Kernel & 3 & 0.041 & Digestive System Disorders & 2 & 0.667 \\
\hline \multicolumn{3}{|l|}{ 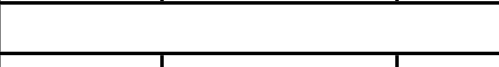 } & III-Defined Symptoms & 1 & 0.333 \\
\hline Bark & 15 & 0.205 & Circulatory System Disorders & 1 & 0.067 \\
\hline & & & Digestive System Disorders & 4 & 0.267 \\
\hline & & & Genitourinary System Disorders & 2 & 0.133 \\
\hline & & & III-Defined Symptoms & 1 & 0.067 \\
\hline & & & Pregnancy/Birth/Puerperium Disorders/Effects & 1 & 0.067 \\
\hline & & & Respiratory System Disorders & 1 & 0.067 \\
\hline & & & Infections/Infestations & 1 & 0.067 \\
\hline & & & Traditional beds & 4 & 0.267 \\
\hline
\end{tabular}


quantitative approach

\begin{tabular}{|c|c|c|c|c|c|}
\hline \multicolumn{6}{|c|}{$R U=73$} \\
\hline Parts & $\mathbf{R} \mathbf{U}_{\text {plant part }}$ & PPV & Specific reported uses & SU & IUV \\
\hline \multirow[t]{7}{*}{ Root } & 10 & 0.137 & Circulatory System Disorders & 1 & 0.100 \\
\hline & & & Digestive System Disorders & 10 & 0.700 \\
\hline & & & Genitourinary System Disorders & 2 & 0.200 \\
\hline & & & III-Defined Symptoms & 1 & 0.100 \\
\hline & & & Pregnancy/Birth/Puerperium Disorders/Effects & 1 & 0.100 \\
\hline & & & Respiratory System Disorders & 1 & 0.100 \\
\hline & & & Infections/Infestations & 1 & 0.100 \\
\hline Timber & 5 & 0.068 & Oral hygiene & 5 & 1.000 \\
\hline \multirow[t]{2}{*}{ Butter } & 17 & 0.233 & Muscular-Skeletal System Disorders & 1 & 0.059 \\
\hline & & & Cosmetics & 16 & 0.941 \\
\hline $\begin{array}{l}\text { Root } \\
\text { sucker }\end{array}$ & 4 & 0.055 & Oral hygiene & 3 & 1.000 \\
\hline
\end{tabular}

Table 3f. Importance indices for the uses of Pentadesma butyracea Sabine organs by Fulani people of Bassila commune, Benin. $\mathrm{RU}_{\text {plant part }}$ plant part reported use; $\mathrm{RU}=$ reported use ; PPV = plant part value ; SU = specific use; IUV $=$ Intraspecific use-value.

\begin{tabular}{|c|c|c|c|c|c|}
\hline \multicolumn{6}{|c|}{$R U=33$} \\
\hline Parts & $R \mathbf{U}_{\text {plant part }}$ & PPV & Specific reported uses & SU & IUV \\
\hline \multirow[t]{5}{*}{ Leaf } & 6 & 0.182 & Digestive System Disorders & 2 & 0.333 \\
\hline & & & Infections/Infestations & 1 & 0.167 \\
\hline & & & $\begin{array}{l}\text { Lactogenic effects/ immune reinforcement and } \\
\text { dentition }\end{array}$ & 1 & 0.167 \\
\hline & & & Tonic & 1 & 0.167 \\
\hline & & & Magico-mystics & 1 & 0.167 \\
\hline Flower & 1 & 0.030 & $\begin{array}{l}\text { Lactogenic effects/immune } \\
\text { reinforcement and dentition }\end{array}$ & 1 & 1.000 \\
\hline \multirow[t]{2}{*}{ Pulp } & 2 & 0.061 & Digestive System Disorders & 1 & 0.500 \\
\hline & & & Magico-mystics & 1 & 0.500 \\
\hline \multirow{6}{*}{$\begin{array}{l}\text { Kernel } \\
\text { Bark } \\
\end{array}$} & 1 & 0.030 & Tonic & 1 & 1.000 \\
\hline & 8 & 0.242 & Circulatory System Disorders & 2 & 0.250 \\
\hline & & & Digestive System Disorders & 1 & 0.125 \\
\hline & & & Genitourinary System Disorders & 3 & 0.375 \\
\hline & & & Pregnancy/Birth/Puerperium Disorders/Effects & 1 & 0.125 \\
\hline & & & Magico-mystics & 1 & 0.125 \\
\hline Root & 3 & 0.091 & Genitourinary System Disorders & 3 & 1.000 \\
\hline \multirow{2}{*}{$\frac{\text { Timber }}{\text { Butter }}$} & 0 & & & & \\
\hline & 0 & & & & \\
\hline $\begin{array}{l}\text { Young } \\
\text { leaf }\end{array}$ & 11 & 0.333 & $\begin{array}{l}\text { Lactogenic effects/immune reinforcement } \\
\text { and dentition }\end{array}$ & 11 & 1.000 \\
\hline Fruit & 1 & 0.030 & Genitourinary System Disorders & 1 & 1.000 \\
\hline
\end{tabular}


Table 3g. Importance indices for uses of Pentadesma butyracea Sabine organs by Natimba people of Toucountouna commune, Benin. $\mathrm{RU}_{\text {plant part }}$ plant part reported use; $\mathrm{RU}=$ reported use ; PPV = plant part value ; $\mathrm{SU}=$ specific use; IUV $=$ Intraspecific use-value.

\begin{tabular}{|c|c|c|c|c|c|}
\hline \multicolumn{6}{|c|}{$R U=34$} \\
\hline Parts & $\mathbf{R U}_{\text {plant part }}$ & PPV & Specific reported uses & SU & IUV \\
\hline \multirow[t]{5}{*}{ Leaf } & 7 & 0.206 & Circulatory System Disorders & 1 & 0.143 \\
\hline & & & Genitourinary System Disorders & 1 & 0.143 \\
\hline & & & III-Defined Symptoms & 1 & 0.143 \\
\hline & & & Pregnancy/Birth/Puerperium Disorders/Effects & 2 & 0.286 \\
\hline & & & Magico-mystics & 2 & 0.286 \\
\hline \multirow[t]{3}{*}{ Pulp } & 3 & 0.088 & Circulatory System Disorders & 1 & 0.333 \\
\hline & & & Respiratory System Disorders & 1 & 0.333 \\
\hline & & & Magico-mystics & 1 & 0.333 \\
\hline Kernel & 0 & 0.000 & & & \\
\hline \multirow[t]{3}{*}{ Bark } & 4 & 0.118 & Circulatory System Disorders & 2 & 0.500 \\
\hline & & & III-Defined Symptoms & 1 & 0.250 \\
\hline & & & $\begin{array}{l}\text { Lactogenic effects/ immune reinforcement and } \\
\text { dentition }\end{array}$ & 1 & 0.250 \\
\hline \multirow[t]{2}{*}{ Root } & 3 & 0.088 & Circulatory System Disorders & 1 & 0.333 \\
\hline & & & Magico-mystics & 3 & 0.667 \\
\hline Butter & 16 & 0.471 & Cosmetics & 16 & 1.000 \\
\hline
\end{tabular}

$=0.435,0.700$ and 0.500 respectively). In contrast, the Kotocoli, Nagot and Fulani respondents reported to use this organ to treat genitourinary system disorders (IUV = $0.750,0.455$ and 1.00 respectively).

The specific uses of leaves were more diversified among sociolinguistic groups than the specific uses of bark and roots. In addition to their use in the healing of wounds, especially after the circumcision of males by the Waama and Ditamari groups (IUV $=0.444$ and 0.429 respectively), leaves were also used to treat digestive system disorder by the Kotocoli and Fulani groups (IUV $=0.750$ and 0.333 respectively).

Only the Anii, Kotocoli and Fulani respondents, for their lactogenic properties and the reinforcement of the immune system and dentition of newborns reported the use of young leaves. The IUV for the three groups was respectively $0.833,0.944$ and 1.00 .

Pulp was reported for cosmetic uses. For instance, the Kotocoli, Waama and Ditamari groups used it in chiropodist and local soap preparation (IUV $=0.667,1.000$ and 1.000 respectively). Because of its tartness, the Nagot and Fulani respondents also reported the pulp in the treatment of digestive system disorders such as bloated stomach and constipation (IUV 0.750 and 0.500 respectively). The processing of kernels into butter, mainly for consumption, and the use of the timber in carpentry were common practices among all sociolinguistic groups. Therefore we have not reported their uses. However, butter was particularly reported as important by the Waama, Ditamari and Natimba respondents for cosmetic uses (traditional soap production, IUV $=0.941,1.000$ and 1.000 respectively). Likewise, the Waama and Ditamari groups reported the use of the wood in oral hygiene (IUV $=1.000)$.

The use of flowers was limited to sociolinguistic groups from Bassila area and consisted of specific uses such as lactogenic effects (Kotocoli and Fulani, IUV equal to 1.000), treatment of digestive system disorders (Anii and Nagot, IUV equal to 0.400 and 0.500 ) and magico-mystic uses. Roots and suckers were reported particularly by sociolinguistic groups from Toucountouna area for oral hygiene (IUV = 1.000). Kernels were used in diverse ways including the treatment of ill-defined symptoms, digestive system disorders, muscular-skeletal system disorders, respiratory system disorders and inflammation.

The use of the entire fruit was limited to a few sociolinguistic groups and did not show any convergence concerning a specific use. In the Kotocoli group, the entire fruit was reported for magico-mystic uses whereas in the Nagot group, it was mentioned in the treatment of digestive system disorders, genitourinary system disorders, ill-defined symptoms and magico-mystic uses. 


\section{Avocèvou-Ayisso et al. - Ethnobotany of Pentadesma butyracea in Benin: A 163 quantitative approach}

\section{Discussion}

This study used four importance indices to investigate similarities in the use knowledge and intercultural convergences of specific uses of $P$. butyracea parts among seven sociolinguistic groups in Benin. The results showed that the seven sociolinguistic groups may be categorized based on their interests or specialization in the various plant parts they used. This suggests that they have their own ideas about which plant parts are suitable for specific purposes (Kristensen \& Lykke 2003). Their cultural difference may reflect their different knowledge levels. Moreover, different communities may develop unique plant knowledge as they are exposed to diverse environments, ailments, and cultural practices (Leonti et al. 2003). For example, the Ditamari people had an IUV of 0.429 for the leaves that they used essentially in dressing wounds after circumcision, a biennial ceremony. Circumcision for this group is deeply established in their tradition because it is tied to the initiation of children into manhood up to the age of 20 years. The interest or specialization that people showed in a particular organ may also reflect a social organization in the uses of the plant. For instance, the greater interest that Waama, Ditamari and Natimba showed in butter compared with Anii, Kotocoli, Nagot and Fulani may be explained by the way the processing of kernels is organized in each region. In Toucountouna, women from all sociolinguistic groups including Waama, Ditamari and Natimba, collect fresh fruits, extract and process the kernels into butter and sometimes use the butter to make traditional soap. In Bassila in contrast, only Fulani women process kernels into butter. Women from other sociolinguistic groups only collect kernels and sell them to Fulani women (Avocèvou-Ayisso et al. 2009).

The results also suggest that groups of the same geographical area generally shared similar part values. This would mean that with time, sociolinguistic groups that are living together exchange their knowledge. These knowledge exchanges can occur through friendships, kinship and inter-ethnical marriages, which are frequent among the studied groups. This trend is supported by the findings of Coe (2008) who identified the geographical proximity of communities as the most influential factor of similarities in the use of plant species among Rama and Miskitu indigenous groups in Nicaragua. It was found to facilitate the exchange of ethnobotanical lore among various indigenous groups. Thus, the local knowledge within a given sociolinguistic group, may include aspects of ancestral knowledge, novel and acquired practical experiences, the knowledge from other neighboring communities, and even regional scholarly traditions and scientific or official knowledge (Nesheim et al. 2006) that may be acquired through interactions with agricultural extension officers (Dhillion \& Gustad 2004, Gadgil et al. 2000). On the other hand, some studies pointed out dissimilarities in plant use knowledge among neighboring social groups. Vande- broek et al. (2004) showed in their work that Andean informants had a more in-depth traditional botanical knowledge of useful medicinal plants than Amazonian peoples in Bolivia had. Moreover, Shepard (2004) in a comparison of two Amazonian and geographically adjacent communities (Matsigenka and Nahua), reported a definite difference in the selection of medicinal plant species. The influence of geographical proximity in our study area is likely because those communities are not living in isolation, except the Fulani people who are a herder community that often live in the bush. They may live in the same village, even in neighboring houses. Moreover, as mentioned earlier, inter-ethnic marriages and friendships are becoming more and more common among those communities.

The reported use values suggest that the Nagot and Waama people mentioned lower average numbers of uses of the species than the Anii, Ditamari, Fulani, Kotocoli and Natimba people did. The low RU may be due to the different types of interest the various communities developed in these plant uses. The Nagot people for instance were more interested in the use of the bark and roots for a few medicinal purposes while the Waama people were more interested in the butter and timber. Within sociolinguistic groups, men seemed to have more use knowledge of the species than women have. Apart from the young leaves which were collected, and kernels which were processed into butter by women, most of the organs of the plant were used in the treatment of diseases. Butter was used in the cooking of meals and the production of traditional soap, while young leaves were mostly used as a vegetable for their lactogenic effects. These uses were directly related to women's responsibilities in households. Men were mainly responsible for the health of the family, and the building and maintenance of houses, activities in which the other parts of the species were more diversely used. Our results confirm the findings of Pfeiffer \& Butz (2005) who reported many cases in which social division of labor and roles influenced differences in plant use knowledge between men and women. No difference in the reported use was observed between young and old people. This result may likely be because in the sampling strategy, we did not consider people aged less than 22 years, who were reported to hold limited knowledge of the species during the exploratory phase.

The results of this study are important in many respects for the conservation and utilization of the species. The cross-culture evaluation of the uses of the species' parts allowed a consensus on some of its uses. This consensus is important in validating the potential uses which extended beyond culture. This cross-culture validation of the uses of the species may be a starting point in the selection of its parts for phytochemical and pharmacological studies. For instance, sociolinguistic groups from different geographic areas - the Anii and Nagot in Bassila, and the Waama and Ditamari in Toucountouna - used the bark to treat digestive system disorders. Moreover, the re- 
sults may allow the identification of areas where harvesting practices may threaten the survival of the species, and dwelling populations to target for awareness actions. Organ harvesting may for instance threaten the species in areas where many Nagot people live, because this community is interested essentially in the bark and roots, two organs critical to the survival of species.

Although this study does not attempt to estimate organ harvest rates, it does address issues of its use simply by looking at the parts used for various purposes. Further studies, may investigate the relationships between the plant use knowledge and its actual uses and harvest rates and infer on the threats it is facing, especially for management and conservation purposes.

\section{Conclusion}

The plant part values used in this study allowed the allocation of a value to each part of $P$. butyracea in various sociolinguistic groups and the comparison of the importance of the species organs among these groups. These people use the species in various ways. Sociolinguistic groups which are living in the same geographical area shared similar values of the species' organs. Several parts of the species were most reported for the same specific use by different sociolinguistic groups. This information is useful for future pharmacological and chemical studies, especially when social groups which are not living in the same geographical area report the same uses. In areas where Nagot people live, the sustainable use of species may be jeopardized because this community is essentially interested in roots and bark, two organs critical to tree survival. The present approach may be completed by the quantification of the species' part harvested by people.

\section{Acknowledgements}

We would like to thank Dominic Byarugaba and Orou Gaoue for constructive feedback on earlier drafts of this manuscript. We are also grateful to Robert Fungo for language proofreading. Thanks to all Bassila and Toucountouna people who shared their knowledge with us.

\section{Literature Cited}

Albuquerque, U.P., R.F.P. Lucena, J.M. Monteiro, A.T.N. Florentino \& C.F.C.B.R. Almeida. 2006. Evaluating two quantitative ethnobotanical techniques. Ethnobotany $R e-$ search and Application 4:051-060.

Ali-Shtayeh M.S., R.M. Jamous, J.H. Al-Shafie', W.A. Elgharabah, F.A. Kherfan, K.H. Qarariah, I.S. Khdair, I.M. Soos, A.A. Musleh, B.A. Isa, H.M. Herzallah, R.B. Khlaif, S.M. Aiash, G.M. Swaiti, M.A. Abuzahra, M.M. Haj-Ali, N.A. Saifi, H.K. Azem \& H.A. Nasrallah. 2008. Traditional knowledge of wild edible plants used in Palestine (North- ern West Bank): A comparative study. Journal of Ethnobiology and Ethnomedicine 4:13.

Arias Toledo, B., S. Colantonio \& L. Galetto. 2007. Knowledge and use of edible and medicinal plants in two populations from the Chaco forest, Co' Rdoba Province, Argentina. Journal of Ethnobiology 27(2):218-232.

Aubreville, A. 1959. La flore forestière de la Côte d'Ivoire. Volume 2. 2nd edition. Publication Centre Technique Forets Tropicals, Paris, France.

Avocèvou-Ayisso, C., B. Sinsin, A. Adégbidi, G. Dossou \& P. Van Damme. 2009. Sustainable use of non-timber forest products: Impact of fruit harvesting on Pentadesma butyracea regeneration and financial analysis of its products trade in Benin. Forest Ecology and Management 257(8):1930-1938.

Ayantunde, A.A., M. Briejer, P. Hiernaux, H.M.J. Udo \& R. Tabo. 2008. Botanical knowledge and its differentiation by age, gender and ethnicity in Southwestern Niger. Human Ecology 36:881-889.

Coe, F.G. 2008. Ethnobotany of the Rama of Southeastern Nicaragua and comparisons with Miskitu plant lore. Economy Botany 62(1):40-59.

Collins, S., X. Martins, A. Mitchell, A. Teshome \& J.T. Arnason. 2006. Quantitative ethnobotany of two east Timorese cultures. Econony Botany 60(4):347-361.

Cook, F.E.M. 1995. Economic Botany Data Collection Standard. Edited by D.V. Prendergast. Royal Botanic Gardens, Kew, United Kingdom.

Dalle, S.P. \& C. Potvin. 2004. Conservation of useful plants: an evaluation of local priorities from two indigenous communities in Eastern Panama. Economy Botany 58(1):38-57.

Dhillion, S.S. \& G. Gustad. 2004. Local management practices influence the viability of the baobab (Adansonia digitata) in different land use types, Cinzana, Mali. Agriculture Ecosystem and Environment 101:85-103.

Fernandez, E.C., Y.E. Sandi \& L. Kokoska. 2003. Ethnobotanical inventory of medicinal plants used in the Bustillo province of the Potosi Department, Bolivia. Filoterapia 74:407-416.

Frei, B., M. Baltisberger, O. Sticher \& M. Heinrich. 1998. Medical ethnobotany of the Zapotecs of the Isthmus-Sierra (Oaxaca, Mexico): Documentation and assessment of indigenous uses. Journal of Ethnopharmacology 62:149165. 


\section{Avocèvou-Ayisso et al. - Ethnobotany of Pentadesma butyracea in Benin: A 165 quantitative approach}

Gadgil, M., S.P.R. Rao, G. Utkarsh, P. Pramod \& A. Chhatre. 2000. New meanings of old knowledge: The people's biodiversity program. Ecological Applications 10(5):13071317.

Gemedo-Dalle, T., B.L. Maass, \& J. Isselstein. 2005. Plant diversity and ethnobotany of Borana Pastoralists in Southern Oromia, Ethiopia. Economic Botany 59(1):43-65.

Giday, M., Z. Asfaw, T. Elmqvist \& Z. Woldu. 2003. An ethnobotanical study of medicinal plants used by the Zay people in Ethiopia. Journal of Ethnopharmacology 85:4352.

Gomez-Beloz, A. 2002. Plant use knowledge of the Winikina Warao: The case for questionnaires in ethnobotany. Economy Botany 56:231-241.

Hadjichambis, A.C.H., D. Paraskeva-Hadjichambi, A. Della, M. Giusti, C. De Pasquale, C. Lenzarini, E. Censorii, M.R. Gonzales-Tejero, C.P. Sanchez-Rojas, J. RamiroGutierrez, M. Skoula, C.H. Johnson, A. Sarpakia, M. Hmomouchi, S. Jorhi, M. El-Demerdash, M. El-Zayat \& A. Pioroni. 2008. Wild and semi-domesticated food plant consumption in seven circum-mediterranean areas. International Journal of Food Sciences and Nutrition 59(2):383414.

Heinrich, M., A. Ankli, B. Frei, C. Weimann \& O. Sticher. 1998. Medicinal plants in Mexico: Healers' consensus and cultural importance. Social Sciences and Medicine 47(11):1859-1871.

Henerson, M.E., L.L. Morris \& C.T. Fitz-Gibbon. 1987. How to Measure Attitudes. SAGE Publications, Newbury Park, California.

Hilgert, N.I. \& G.E. Gil. 2006. Medicinal plants of the Argentine Yungas plants of the Las Yungas biosphere reserve, Northwest of Argentina, used in health care. Biodiversity Conservation 15:2565-2594.

Houngbédji, A. 1997. Étude phytotechnique, écologique et des technologies endogènes de transformations de Pentadesma butyracea, espèce des galeries forestières de la région de Bassila. Dissertation, Lycée technique agricole Médji de Sékou, Porto-Novo, Benin.

Hutchinson, J. \& J.M. Dalziel. 1954. Flora of West Tropical Africa. Whitefriards Press Ltd., London.

INSAE (Institut National de la Statistique et de l'Analyse Economique). 2006. Population par arrondissement du Bénin en 2002 et 2006 et population en âge de voter en 2006. www.insae-benin.org
Kristensen, M. \& A.M. Lykke. 2003. Informant-based valuation of use and conservation preferences of savanna trees in Burkina Faso. Economy Botany 57(2):203-217.

Leonti, M., R.R. Fernando, O. Sticher \& M. Heinrich. 2003. Medicinal flora of the Popoluca, Mexico: A botanical systemical perspective. Economy Botany 57(2):218-230.

Luoga, E.J., E.T.E. Witkowski \& K. Balkwill. 2000. Differential utilization and ethnobotany of trees in Kitulanghalo forest reserve and surrounding communal cands, Eastern Tanzania. Economy Botany 54(3):328-343.

Lykke, A.M. 2000. Local perceptions of vegetation change and priorities for conservation of woodysavanna vegetation in Senegal. Journal of Environmental Management 59:107-120.

Natta, A.K., B. Sinsin \& L.J.G. Van der Maesen. 2002. Riparian forests, a unique but endangered ecosystem in Benin. Botanische Jahrbücher für Systematik 124:55-69.

Natta, A.K., Th.A. Sinadouwirou, B. Sinsin \& L.J.G. Van der Maesen. (2003) Spatial distribution and ecological factors determining the occurrence of Pentadesma butyracea Sabine (Clusiaceae) in Benin. Pp. 73-80 in Ecological Assessment of Riparian Forests in Benin: Phytodiversity, phytosociology and spatial distribution of tree species. Edited by A. Natta. Dissertation, Wageningen University, Wageningen, The Netherlands.

Nesheim, I., S.S. Dhillion \& K.A. Stølen. 2006. What happens to traditional knowledge and use of natural resources when people migrate? Human Ecology 34(1)99-131.

Pfeiffer, J. \& R. Butz. 2005. Assessing cultural and ecological variation in ethnobotanical research: The importance of gender. Journal of Ethnobiology 25(2):240-287.

Phillips, O. \& A.H. Gentry. 1993a. The useful plants of Tambopata, Peru: I. Statistical hypothesis tests with a new quantitative technique. Economy Botany 47:15-32.

Phillips, O. \& A.H. Gentry. 1993b. The useful plants of Tambopata, Peru: II. Additional hypothesis testing in quantitative ethnobotany. Economy Botany 47:33-43.

Phillips, O. 1996. Some quantitative methods for analyzing ethnobotanical knowledge. Pp. 171-197 in Selected Guidelines for Ethnobotanical Research: A field manual. Advances in Economic Botany, volume 10. Edited by M.N. Alexiades. The New York Botanical Garden Press, New York.

Projet de Restauration des Ressources Forestières dans la région Bassila. 1998. Plan d'aménagement participatif de la forêt classée de Pénessoulou. Office National du 
Bois, GTZ-Luso consult DFRN, Ministère du Développement Rural, Cotonou, Bénin.

Sama, B. \& M. Sacandé. 2007. Pentadesma butyracea Sabine. Seed Leaflet 131.

Shepard, Jr.G.H. 2004. A sensory ecology of medicinal plant therapy in two Amazonian societies. American Anthropologist 106:252-266.

Sinsin, B. \& Th. Sinadouwirou. 2003. Valorisation socioéconomique et pérennité du $P$. butyracea Sabine en galeries forestières au Bénin. Cahier Agriculture 12:1-5.
Turner, M.D., \& P. Hiernaux. 2002. The use of herders' accounts to map livestock activities across agropastoral landscapes in Semi-Arid Africa. Landscape Ecology 17:367-385.

Vandebroek, I., P. Van Damme, L. Van Puyvelde, S. Arrazola \& N. De Kimpe. 2004. A comparison of traditional healers' medicinal plant knowledge in the Bolivian Andes and Amazon. Social Science \& Medicine 59:837-849.

Vivien, J. \& J.J. Faure. 1988. Fruitiers sauvages du Cameroun. Fruit 43:585-601. 